\title{
Economic Policy Uncertainty, Shareholding of Institutional Investors and R\&D Investment of High Technology Enterprises: Evidence from China
}

\author{
Yuxin Zhou $^{1,2}$
}

\author{
${ }^{1}$ University of Birmingham, B15 2TT \\ ${ }^{2}$ Southwestern University of Finance and Economics, 611130 \\ *Email:YXZ093@student,bham.ac.uk
}

\begin{abstract}
This paper studies how economic policy uncertainty affect the R\&D investment of Chinese high technology enterprises. Meanwhile, it examines the moderating effect of shareholding of institutional investors. Our results show that the proportion of high technology enterprises' R\&D investment is positively correlated with the EPU level of that year. Furthermore, higher shareholding of institutional investors reinforced this positive effect.
\end{abstract}

Keywords: Economic policy uncertainty, Shareholding of Institutional Investors, $R \& D$ investment, High technology enterprises

\section{INTRODUCTION}

This study examines the relationship among economic policy uncertainty (EPU), shareholding of institutional investors and the research and development (R\&D) investment of high technology enterprises in China.

Under the background of increasing uncertainty in the international community, issues such as the Sino-US trade friction and the Cov-19 virus pandemic have caused frequent alternation of economic policies and regulations around the world. Research has shown that when the degree of EPU is higher, firms stand to lower their investment [1]. Most relevant study in the past mainly focused on the influence of EPU on the economy as a whole. It is not until recently that scholars began to look into its impact at the enterprise level. These researches include fields such as cash holding level and market value [2] and financial restriction and enterprise innovation [3]. However, there are few researches emphasizing the importance of R\&D aspect of enterprises, especially for those new technology-based firms. Evidence suggests that $R \& D$ investment significantly promotes the increase corporate value of companies listed on Sci-Tech Innovation Board [4]. As a result, this paper intended to investigate the how EPU affect the R\&D investment of high technology enterprises.
Meanwhile, studies have also illustrated that different enterprise ownership structures can lead to different attitudes toward R\&D investment. Evidence has shown that managers are less likely to cut R\&D to reverse earnings decline when institutional ownership is high [5]. Accordingly, when examining the impact of EPU on the R\&D investment of high technology enterprises, the moderating effect of shareholding of institutional investors cannot be overlooked.

To measure EPU, we adopt the index of EPU developed by Baker et al. [6], which has been proved to be a good indicator of the uncertainty level of policy for real economy [7].

Using a panal of over 1000 high technology enterprises, we find out the influence of EPU on R\&D investment of enterprises in the following way: EPU increases the R\&D investment of high technology enterprises. Meanwhile, by adding shareholding of institutional investors as a moderator, the result shows higher shareholding of institutional investors increases EPU's positive effect on R\&D investment of high technology enterprises in China.

In this paper, the main hypotheses of our research are illustrated in the following section, followed by the demonstration of the sample data and choice of variables in the third section. The fourth and fifth section present the empirical results and conduct robustness tests 
respectively. Finally, we come to our conclusion in the last section.

\section{RELATED LITERATURE HYPOTHESES DEVELOPMENT}

AND

\subsection{EPU and R\&D investment of high technology enterprises}

Traditionally, it is widely believed that higher EPU level will depress enterprises' investment for various reasons. Initially, enterprises tend to be in favour of more basic needs and hold back consumption. Study has demonstrated that companies are more cautious when the instability of regulation casts doubt on their costs and revenue ${ }^{[8]}$. Meanwhile, when uncertainty appears, production, employee compensation and corporate investments may need to be cut down.

However, this view may only apply for firms of average size or in traditional fields. The investment decisions of the top 20\% largest listed firms are not likely to be affected by policy uncertainty [8]. Also, evidence suggests that although EPU is inversely related to the investment of traditional energy enterprises, it will promote that of renewable, energy enterprises [9].

In addition, in terms of innovation, study shows although EPU is usually assumed to hinder firm investments as it causes unexpected market conditions, there is a positive relationship between EPU and firm R\&D expenditure [10].

To further explore more detailed conclusion, this paper mainly focuses on the effect of EPU level on R\&D investment of high technology enterprises. Based on the analysis above, we formulate the first hypothesis:

$\mathrm{H}_{1}$ : EPU increases the R\&D investment of high technology enterprises.

\subsection{Moderating effect of shareholding of institutional investors}

Institutional investors have the ability to collect and analyse public information and own a large proportion of corporations' stock. Accordingly, they are usually the most influential shareholders among all. There is no final conclusion over whether there is a positive or negative relationship between shareholding of institutional investors and $\mathrm{R} \& \mathrm{D}$ investment of an enterprise.

It is commonly believed that institutions, which have more professional skills and resources, pay more attention on long-term benefits and tend to promote innovation. Institutional investors can affect managers' planning horizon and their attitudes toward long-term investment, which leads to increase in companies' R\&D spending [11]. Meanwhile, institutions tend to employ activism to increase $R \& D$ investment both in the short run and long run [12]. It has also been proved that shareholdings of institutional investors can significantly facilitate enterprises' innovation quality [13]. On the other hand, others argue that such investors emphasis primarily short-term return from investment activity [14]. Institutional ownership appears to have a negative effect on R\&D expenditures [15]. Particularly, short term institutional ownership is negatively related to the innovation outputs [16].

However, at the same time, there is evidence suggesting that institution investors can increase enterprises' resilience to uncertainty. For instance, institutions investors are likely to mitigate the negative effect of environmental uncertainty on companies' investment efficiency [17]. As the proportion of institutional investors increases, the positive correlation between environmental uncertainty and inefficient investment tend to decrease [18].

Therefore, it is likely that shareholding of institutional investors has a moderating effect on EPU's influence on companies' R\&D investment and we posit the second hypothesis as:

$\mathrm{H}_{2}$ : Higher shareholding of institutional investors increases EPU's positive effect on R\&D investment of high technology enterprises.

\section{RESEARCH DESIGN}

\subsection{Sample selection and data sources}

To study the influence of EPU on R\&D investment, we employ a sample of 1464 listed Chinese high technology enterprises' financial statement data from 2015 to 2019, which comes from the CSMAR database. The EPU index of the period studied is obtained from the EPU index website.

\subsection{Selection of variables}

Table 1. Variables

\begin{tabular}{cc}
\hline Variables & Definition \\
\hline RD & R\&D Expenditure/Operating Revenue \\
IRDE & In(Percentage of R\&D employees) \\
EPU & EPU Index \\
Ins \\
EPUIns & Shareholding of Institutional investors \\
EPU*Ins \\
Size \\
Age & In(Total Assets) \\
Grow & Enterprise Age \\
Lev & Growth Rate of Operating Revenue \\
Q & Total Liability/Total Assets \\
Cashflow & Tobin's q \\
ROA & Cashflow \\
ROE & Return on Assets \\
& Return on Equity \\
\hline
\end{tabular}

\subsubsection{Dependent variable}

To measure enterprises' R\&D investment, we select the data of $R \& D$ expenditure from the financial statements of the 1646 high technology enterprises. The 
ratio of $R \& D$ expenditure to operating revenue is used to acquire a single standard to compare the level of $\mathrm{R} \& \mathrm{D}$ investment of these companies (RD).

\subsubsection{Independent variable}

In accordance with most domestic and foreign literatures, the EPU index of China developed by Baker is used. This criterial has proved to be a proper and accurate measurement of the level of economic policy uncertainty [19]. To transfer the monthly data to an annual one, we take the arithmetic means of the twelve monthly EPU index as the annual EPU index of the year (EPU).

\subsubsection{Moderator variable}

Based on the analysis above, the proportion of shareholding of institutional investors is used to act as a moderator in the relationship between EPU and R\&D investment of high technology enterprises, which is calculated by the percentage of shares outstanding held by institutional investors at the end of each year studied.

\subsubsection{Control variable}

Referring to related studies, our main control variables are size (Size), age (Age), growth rate of operating revenue (Grow), leverage ratio (Lev), Tobin's $q(\mathrm{Q})$, return on assets $(\mathrm{ROA})$, return on equity (ROE) and cashflow (Cashflow).

\subsection{Model construction}

Referring to the study of Qun Gu [1], we formulate the following multiple linear regression models to verify our hypothesis.

For hypothesis $\mathrm{H}_{1}$,

$$
R D_{i, t}=\beta_{0}+\beta_{1} E P U_{t}+\alpha C O N T R O L S+\varepsilon_{i, t}
$$

To test whether the hypothesis is true, we need to examine whether the parameter $\beta_{1}$ is greater than zero.

For hypothesis $\mathrm{H}_{2}$,

$$
R D_{i, t}=\delta_{0}+\delta_{1} E P U_{t}+\delta_{2} I n s_{t}+\delta_{3} E P U_{t} \times I n s_{t}+\delta C O N T R O L S+\varepsilon_{i,}
$$

In this model, we need to see whether $\delta_{3}$ is greater than zero in order to verify that higher shareholding of institutional investors increases EPU's positive effect on R\&D investment of high technology enterprises.

\section{EMPIRICAL RESULTS}

\subsection{Descriptive statistics}

The main variables and the corresponding descriptive statistics are illustrated in Table 2. The figures of RD vary from 0 to 307.72 , with 4.74 and 6.38 as mean value and standard deviation respectively, which shows great difference in enterprises' attitude toward R\&D investment.

Table 2. Descriptive statistics

\begin{tabular}{lcccc}
\hline Variable & Mean & Std. Dev. & Min & Max \\
\hline RD & 4.74 & 6.38 & 0 & 307.72 \\
EPU & 4.33 & 2.01 & 1.81 & 7.92 \\
Ins & 6.79 & 6.70 & 0 & 53.89 \\
\hline
\end{tabular}

Meanwhile, the minimum and maximum value of EPU are 1.81 and 7.92 respectively, with a 4.33 mean value and a 2.01 standard deviation. The values of Ins vary from 0 to 53.89, with a mean of 6.79 and a standard deviation of 6.70. In general, there is considerable variation in the each variable and thus the analysis is of feasibility.

\subsection{Basic regression}

From Table 3 we can see that the regression coefficient of the independent variable EPU is 0.1685 with $1 \%$ statistical significance. The basic regression demonstrates that EPU can significantly promote high technology enterprises' R\&D investment, which is consistent with hypothesis $\mathrm{H}_{1}$. When there is higher level of EPU, enterprises tend to put more emphasis on investment concerning innovation and new researches.

\begin{tabular}{|c|c|c|}
\hline & (1) & (2) \\
\hline & $\mathrm{RD}$ & $\mathrm{RD}$ \\
\hline \multirow[t]{2}{*}{ EPU } & $0.1685^{\star * *}$ & $0.1144^{\star \star \star}$ \\
\hline & $(7.4830)$ & $(4.0482)$ \\
\hline \multirow[t]{2}{*}{ Ins } & & $-0.0428^{\star *}$ \\
\hline & & $(-3.0674)$ \\
\hline \multirow[t]{2}{*}{ EPUIns } & & $0.0084^{* *}$ \\
\hline & & (3.0047) \\
\hline \multirow[t]{2}{*}{ Size } & $-0.4798^{\star}$ & $-0.5458^{\star \star}$ \\
\hline & $(-2.3785)$ & $(-2.6538)$ \\
\hline \multirow[t]{2}{*}{ Age } & $-0.0812^{\star \star *}$ & $-0.0830^{* * *}$ \\
\hline & $(-3.5791)$ & $(-3.6593)$ \\
\hline \multirow[t]{2}{*}{ Grow } & $0.0137^{*}$ & $0.0142^{*}$ \\
\hline & $(2.0246)$ & (2.0924) \\
\hline \multirow[t]{2}{*}{ Lev } & $-2.9140^{\star \star \star}$ & $-2.8872^{* * *}$ \\
\hline & $(-7.1145)$ & $(-7.0000)$ \\
\hline \multirow[t]{2}{*}{$Q$} & $0.1386^{* * *}$ & $0.1374^{\star \star \star}$ \\
\hline & (5.1105) & (5.0699) \\
\hline \multirow[t]{2}{*}{ Cashflow } & -0.0000 & -0.0000 \\
\hline & $(-0.0503)$ & $(-0.1124)$ \\
\hline ROA & $-2.8605^{\star \star \star}$ & $-2.8390^{* * *}$ \\
\hline
\end{tabular}

Table 3. Regression results 


\begin{tabular}{lll} 
& $(-8.0093)$ & $(-7.9518)$ \\
$\mathrm{ROE}$ & -0.0073 & -0.0069 \\
& $(-0.7963)$ & $(-0.7561)$ \\
cons & $11.3329^{* * *}$ & $12.2994^{* * \star}$ \\
& $(5.9423)$ & $(6.3179)$ \\
\hline $\mathrm{N}$ & 5738 & 5738 \\
$\mathrm{R}^{2}$ & 0.0173 & 0.0191 \\
\hline${ }^{\mathrm{t}}$ statistics in parentheses & \\
${ }^{*} \mathrm{p}<0.05,{ }^{* *} \mathrm{p}<0.01,{ }^{* * *} \mathrm{p}<0.001$ &
\end{tabular}

\subsection{Moderator effect}

Table 3 shows that after controlling for other factors, the coefficient of EPUINS, which is the cross product of EPU and Ins, is 0.0084 , which is significantly positive at the $5 \%$ level. This result confirms the hypothesis $\mathrm{H}_{2}$ that higher shareholding of institutional investors increases EPU's positive effect on R\&D investment of high technology enterprises and verifies Ins's role as a moderator. This is due to the fact that institutional investors are more likely to pay more attention on longterm benefits and have relatively more professional skills and resources. Accordingly, high technology enterprises with higher proportion of shareholdings of institutional investors tend to invest more on $R \& D$ activities.

\section{ROBUST TEST}

To further confirm the reliability of the study, the result of additional robustness tests is shown in Table 4. In the tests, the dependent variable Ins is replaced by the logarithm of the proportion of the enterprises' $R \& D$ employees of the same companies. The percentage of employees in R\&D department well represents firms' willingness to invest in $R \& D$ activities. To accord to the magnitude of Ins, the logarithm of the data is utilized.

Table 4 also shows that the main results of the new regression are in accordance with those in the main regression, with positive coefficients of EPU and negative coefficient of EPUIns. Meanwhile, there is relatively high significance of the regression result. This indicates that the results are robust and reliable.

Table 4. Robust tests

\begin{tabular}{lll}
\hline & $(1)$ & $(2)$ \\
& IRDE & IRDE \\
\hline EPU & $0.0362^{* * *}$ & $0.0316^{* * *}$ \\
Ins & $(10.0380)$ & $(7.3052)$ \\
& & -0.0034 \\
EPUIns & & $(-1.6516)$ \\
& & 0.0008 \\
Size & & $(1.9451)$ \\
& & $-0.1836^{* \star *}$ \\
Age & $-0.1721^{* * *}$ & $(-5.1209)$ \\
& $(-4.9004)$ & -0.0019 \\
Grow & -0.0017 & $(-0.4528)$ \\
& $(-0.3971)$ & 0.0026 \\
Lev & 0.0025 & $(1.5185)$ \\
& $(1.4658)$ & $-0.2784^{* * *}$ \\
Q & $-0.2861^{* * *}$ & $(-4.1553)$ \\
& $(-4.3022)$ & $0.0095^{*}$ \\
Cashflow & $0.0094^{*}$ & $(2.3998)$ \\
& $(2.3758)$ & -0.0000 \\
ROA & -0.0000 & $(-0.3205)$ \\
& $(-0.2837)$ & -0.0704 \\
ROE & -0.0744 & $(-1.0745)$ \\
& $(-1.1357)$ & 0.0024
\end{tabular}

\begin{tabular}{lll} 
& $(1.7938)$ & $(1.8129)$ \\
$\_$cons & $4.1321^{* * *}$ & $4.2668^{* \star *}$ \\
& $(12.5705)$ & $(12.6964)$ \\
\hline $\mathrm{N}$ & 5738 & 5738 \\
$\mathrm{R}^{2}$ & 0.0309 & 0.0314 \\
\hline \multicolumn{2}{c}{${ }^{*}$ statistics in parentheses } & \\
${ }^{*} \mathrm{p}<0.05,{ }^{* \star} \mathrm{p}<0.01,{ }^{* \star \star} \mathrm{p}<0.001$ &
\end{tabular}

\section{CONCLUSIONS AND SUGGESTIONS}

\subsection{Conclusions}

This paper mainly focuses on two factors that influence high technology enterprises' R\&D investment. Firstly, the R\&D investment of high technology enterprises is positively correlated with the level the country's EPU. Furthermore, as a moderator, shareholding of institutional investors reinforces EPU's positive effect on R\&D investment.

During periods of uncertainty, institutions equipped with professional knowledge and sufficient information are likely to pay more attentions to long-term benefits and development potential of companies. This results in higher R\&D investment of those high technology enterprises.

\subsection{Suggestions}

Initially, given that high technology industries' attitude toward R\&D development, when EPU is high, governments may consider to promote innovation and advance industry reform with proper regulatory tools and subsidy to increase incentive of R\&D. Meanwhile, governments can also encourage institutional investors and high technology enterprises to deepen cooperation. In this way, institutions with long-term vision can facilitate companies to allocate their resources more reasonably and thus obtain better development and innovation opportunities.

\section{REFERENCES}

[1] Qun Gu, Wenwen Wang, Min Li, Economic Policy Uncertainty, Institutional Investors and $\mathrm{R} \& \mathrm{D}$ Investment — Based on the Perspective of R\&D Heterogeneity, Soft Science, 34.02(2020):21-26. DOI:10.13956/j.ss.1001-8409.2020.02.04.

[2] Hongjian Wang, Qingyuan Li, and Fei Xing, Economic policy uncertainty, cash holdings and its market value, Journal of Financial Research, 09(2014):53-68.

DOI:

CNKI:SUN:JRYJ.0.2014-09-004.

[3] Juanjuan Chen, Hongyan Zhao, Xiaoli Yang, Economic Policy Uncertainty, Financing Constraint and Firm Innovation, 40.02(2021):55-60. DOI: CNKI:SUN:YUCE.0.2021-02-008.

[4] Chunyang Zhang, Peirong Ying, Research on the Correlation between R\&D Investment and 
Corporate Value of Listed Companies on the Science and Technology Innovation Board, China Township Enterprises Accounting, 03(2021):18-20. DOI: CNKI:SUN:XQKJ.0.2021-03-009.

[5] Bushee, Brian J, The influence of institutional investors on myopic R\&D investment behavior, Accounting review (1998): 305-333.

[6] Baker, Scott R., Nicholas Bloom, and Steven J. Davis, Measuring economic policy uncertainty, The quarterly journal of economics

[7] Pingui Rao, Heng Yue, Guohua Jiang, Economic Policy Uncertainty and Firms' Investment, The Journal of World Economy 40.02(2017):27-51. DOI:CNKI:SUN:SJJJ.0.2017-02-003.

[8] Kang, Wensheng, Kiseok Lee, and Ronald A. Ratti, Economic policy uncertainty and firm-level investment, Journal of Macroeconomics 39 (2014): 42-53.

[9] Liu, Rongyan, et al, Is there any difference in the impact of economic policy uncertainty on the investment of traditional and renewable energy enterprises?-A comparative study based on regulatory effects, Journal of Cleaner Production 255 (2020): 120102.

[10] Hui Jiang, Caiyun Liu (2020) Economic policy uncertainty, CEO characteristics and firm R\&D expenditure: a Bayesian analysis, Applied Economics, 52:34, 3709-3731, DOI: $10.1080 / 00036846.2020 .1721422$

[11] Eng, Li Li, and Margaret Shackell, The implications of long-term performance plans and institutional ownership for firms' research and development (R\&D) investments, Journal of Accounting, Auditing \& Finance 16.2 (2001): 117-139.

[12] David, Parthiban, Michael A. Hitt, and Javier Gimeno, The influence of activism by institutional investors on $\mathrm{R} \& \mathrm{D}$, Academy of management Journal 44.1 (2001): 144-157.

[13] Zhongze Li, Does Institutional Holdings Promote the Quality of Corporate Innovation, Journal of Shanxi University of Finance and Economics 42.11(2020):85-98.

DOI: 10.13781/j.cnki.1007-9556.2020.11.007.

[14] Drucker, Peter. Innovation and entrepreneurship. Routledge, 2014.

[15] Samuel, Cherian. Stock market and investment: The governance role of the market. The World Bank, 1999.
[16] Kim, Hyun - Dong, Kwangwoo Park, and Kyojik Roy Song, Do long - term institutional investors foster corporate innovation?, Accounting \& Finance 59.2 (2019): 1163-1195.

[17] Hang Qi, Environmental uncertainty, institutional investors and corporate investment efficiency, 2020.

[18] Baiyu Hu, Research on the Impact of Environmental Uncertainty on Inefficient Investment Based on the Perspective of Institutional Investors, 2020, MA thesis.

[19] Fengyu Li, Yongdong Shi, Economic uncertainty and corporate cash holding strategy: Emprical research by using China economic policy uncertainty index, Journal of Management Sciences in China, 19.06(2016):157-170. DOI: CNKI:SUN:JCYJ.0.2016-06-011. 